\title{
$y=2$
$y$ \\ Current Distributions and Dissolution Mechanisms During Localized Corrosion of Steels In Alkaline Environments
}

\author{
Hugh S. Isaacs and Mary P. Ryan \\ Department of Applied Science \\ Brookhaven National Laboratory \\ Upton NY 11973 \\ and \\ Sannakaisa Virtanen and Patrik Schmuki \\ Institute of Materials Chemistry and Corrosion \\ Swiss Federal Institute of Technology \\ ETH-Hoenggerberg \\ 8093 Zurich, Switzertand
}

\begin{abstract}
In situ corrosion investigations of iron were carried out in alkaline environments to determine the stages of corrosion that may be encountered with steels in concrete. The electrochemical and chemical processes taking place on $\mathrm{Fe}$ have been studied using $x$-ray absorption, current density mapping of the iron surface and artificial pits. The $x$ ray absorption near edge spectroscopy was used to observe the conversion of $\mathrm{Fe}$ to oxide in hydroxide solutions. The oxide formed was electrochemically active and changes in valence states between $2+$ and $3+$ were observed during electrochemical cycling between the passive state and bydrogen evolution. The oxide continued to thicken during the cycling with very little dissolution or any conversion back to the metallic state. Current density mapping in chloride/hydroxide solution showed that corrosion took place in highly localized areas confined by the formation of a corrosion product shell. The activity within the shell decayed on removing a supporting cathodic area limiting but reactivated on its replacement Artificial pits were used to study the anodic processes taking place within the region confined by the corrosion product shell. The local $\mathrm{pH}$ and anodic behavior were similar to that observed in neutral or slightly acid bulk solutions. The
\end{abstract}

dissolution within the artificial pits in alkaline bulk solutions was found to be sensitive to the presence of small quantities of nitrite.

\section{INTRODUCTION}

The corrosion of steels in concrete initially takes place in crevices with highly alkaline environments that are present between the concrete and the steel. In order to define the role of inhibitors a study has been made of the behavior of pure iron in alkaline solutions and solutions with chlorides and nitrites. Under most conditions corrosion of steel initiates at inclusions (1) and takes place by the undermining of the passive layer $(2,3)$ as a consequence of an aggressive environment that prevents repassivation of the steel. Inhibitors may act by changing the nature of the passive film and prevent its breakdown or by preventing the buildup of the aggressive environment that is maintained during active dissolution under the passive layer.

\section{EXPERIMENTAL}

The samples were of pure (99.985\%) Fe. For the $x$-ray absorption experiments evaporated $\mathrm{Fe}$ layers were deposited on Mylar sheets coated with a layer of titanium that acted as a current collector. The Fe layer was kept as thin as possible so that changes in the
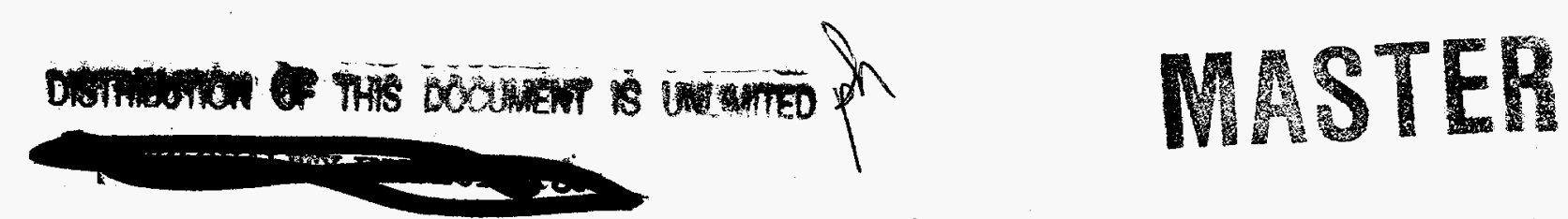
chemistry of the Fe due to the formation of the passive oxide was a significant fraction of the total amount of Fe present. Most Fe films were of the order of $10 \mathrm{~nm}$ thick. The plastic sheet was used to form a window of a cell with the metal layer in contact with the solution. The monochromatic $x$-ray beam passed through the plastic and metal. The fluorescence of the $F e$ as a function of $x$ ray energy was measured and was directly proportional to the absorption by the Fe. Specific details of the technique are given in a number of publications. $(4,5)$

Current density mapping was carried out on the cross section of insulated Fe rods $3 \mathrm{~mm}$ in diameter. The surface was abraded silicon carbide paper down to 600 \#. A vibrating probe that converts the Obmic potential gradients (or IR drops) from a dc to an ac signal, was used to measure the local current density above the metal surface in a $1.0 \mathrm{M} \mathrm{NaCl}$, $0.1 \mathrm{M} \mathrm{NaOH}$ solution following methods and cells used previously. $(6,7)$

Pencil or wire-type artificial pits were used to investigate the dissolution characteristics during localized corrosion. $(3,8,9)$ Wires of the $\mathrm{Fe}, 1 \mathrm{~mm}$ in diameter were imbedded in epoxy and the cross-section of the abraded wire was dissolved back to produce a pit. When additions of $\mathrm{NaNO}_{2}$ were made to bulk solutions the concentrations given arefinal values after the addition.

Potentials are referred to the reference electrodes used in the experiments. The mercury sulfate electrode has a potential $0.4 \mathrm{~V}$ more positive than the saturated calomel electrode.

\section{RESULTS AND DISCUSSION}

Figure 1 shows XANES measurements at $-0.2 \quad V_{\text {mse }}\left(+0.2 \quad V_{s c o}\right)$ during repeated stepping cycles between -0.2 and $-1.6 \mathrm{~V}_{\text {mee }}$. It shows the behavior of the passive film on $\mathrm{Fe}$ in alkaline solutions, in the absence of chloride. Little if any $\mathrm{Fe}$ dissolved and the thickness of the oxide present increased in thickness with potential stepping. The conversion of metal resulted in the progressive shift in the edge to higher energies with cycling. A small loss of about $15 \%$ of Fe originally present was determined from a drop in height of the absorbance step (measured at $7300 \mathrm{eV}$, well above the edge) which sums the contribution from all $\mathrm{Fe}$ species present. The loss occurred during the 15 cycles and set the maximum value for $\mathrm{Fe}$ dissolution or other causes, such as flaking of the deposit. The fraction of un-converted Fe metal remaining after the 15 cycles was estimated from the first knee at lower energies which was dominantly from the spectrum of $\mathrm{Fe}$ metal. It had dropped by about $55 \%$ indicating approximately half the iron still remained. XANES measurements at -1.6 $V_{\text {mec }}$ were in agreement with earlier work (4) where the reduced oxide was composed of divalent Fe. A

comparison of the changes observed with XANES can be made with polarization measurements. Figure 2 show's the first and fif th repeated voltametry cyclic at 10 $\mathrm{mV} / \mathrm{s}$ with an inset of five cycles. Current peaks increased in size indicating that the oxide was thickening with each cycle. From the XANES results this was caused by a thickening oxide and was not due to other causes for example an increased surface area of metal with each oxidation/ reduction cycle.

Scanning vibrating probe measurements of the corrosion behavior of pure $\mathrm{Fe}$ in $0.1 \mathrm{M} \mathrm{NaOH} / 1.0 \mathrm{M} \mathrm{NaCl}$ solutions were carried out with $3 \mathrm{~mm}$ diameter rods i.e. $0.07 \mathrm{~cm}^{2}$. Corrosion was initiated by connecting a Pt wire to increase the potential. A finger of corrosion product formed starting from the edge of the sample and stopped when the $\mathrm{Pt}$ was disconnected. Figure 3A shows the sample when the $P t$ was disconnected. Figure 3B shows the distribution of the normal component of the current density above the surface. 


\section{DISCLAIMER}

This report was prepared as an account of work sponsored by an agency of the United States Government. Neither the United States Government nor any agency thereof, nor any of their employees, make any warranty, express or implied, or assumes any legal liability or responsibility for the accuracy, completeness, or usefulness of any information, apparatus, product, or process disclosed, or represents that its use would not infringe privately owned rights. Reference herein to any specific commercial product, process, or service by trade name, trademark, manufacturer, or otherwise does not necessarily constitute or imply its endorsement, recommendation, or favoring by the United States Government or any agency thereof. The views and opinions of authors expressed herein do not necessarily state or reflect those of the United States Government or any agency thereof. 


\section{DISCLAIMER}

Portions of this document may be illegible electronic image products. Images are produced from the best available original document. 
High anodic currents were observed over the corrosion product with the highest currents above the tip of the finger. On disconnecting the $\mathrm{Pt}$ the currents dropped dramatically and then slowly decayed away with the surrounding passive surface acting as the cathode. The changes can be seen from Figure $2 \mathrm{C}$, and 2D. The corrosion re-initiated when the $\mathrm{Pt}$ was reconnected and the corrosion product spread form the side of the finger.

In order to investigate the effects of inhibitors on dissolution within the corrosion covered volume, artificial wire type pits were used. Figure 4 show's one set of results where the potential was cycled from -0.7 to $2.0 \mathrm{~V}_{\mathrm{sc}}$. Corrosion initiated at $-0.2 \mathrm{~V}_{s e}$ during the first cycle. Each subsequent cycle involved active dissolution of $\mathrm{Fe}$ producing the maximum current when supersaturation of the dissolved products lead to precipitation of a salt layer and a minimum of current, on increasing the potential. The salt layer remained throughout the remaining part of the cycle until the potential decreased

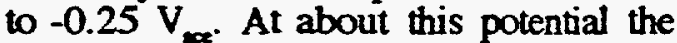
current dropped and the salt layer dissolved. The open circuit potential in the pit was about $-0.5 \mathrm{~V}_{\mathrm{se}}$. With increased depth of the pit the currents decreased because of increased diffusion path. The behavior was similar to that in neutral or acid chloride solutions except for the precipitation of the dissolution products at the mouth of the pit which further inhibited diffusion. With high, 1.0 M concentrations of nitrite, added on the 10th cycle, the current dropped and the pit surface repassivated. Details of the effect is shown inset in Figure 4. Also shown in Figure 5, when small additions of $0.005 \mathrm{M} \mathrm{NaNO}_{2}$ were made distinct decreases in current were observed for the artificial pits held at a fixed potential.

\section{ACKNOWLEDGMENTS \\ This research was performed \\ under the auspices of the U.S. Department of Energy, Division of Materials Science, Office of Basic Energy}

Sciences under Contract No. DE-ACO2$76 \mathrm{CHOOO16.}$

\section{REFERENCES}

1. A J. Sedricks Corrosion of Stainless Steel, John Wiley and Sons, New' York, 1979, p.74.

2. H. S. Isaacs, Corrosion Sci, 34, 525 (1993).

3. G. T. Gaudet, W. T. Mo, T. A. Hatton, J. W. Tester, J. Tilly, H. S. Isaacs, and R. C. Newman, AIChE Journal, 32, 949 (1986).

4. A. J. Davenport, J. A. Bardwell and C. M. Vitus, J. Electrochem. Soc., 142, 721 (1995).

5. A. J. Davenport, H. S. Isaacs, G. S. Frankel, A. G. Schrott, C. V. Jahnes and M. A. Russak, J. Electrochem. Soc., 138, 337 (1993).

6. H. S. Isaacs, A. J. Davenport and A. Shipley, J. Electrochem. Soc., 138, 390 (1991).

7. A. J. Aldykiewicz, H. S. Isaacs and a. J. Davenport, J. Electrochem. Soc., 142, 3342 (1995).

8. J. W. Tester and H. S. Isaacs, J. Electrochem. Soc., 122, 1438 (1975).

9. U. Steinsmo and H. S. Isaacs, J. Electrochem. Soc., 140, 643 (1993). 


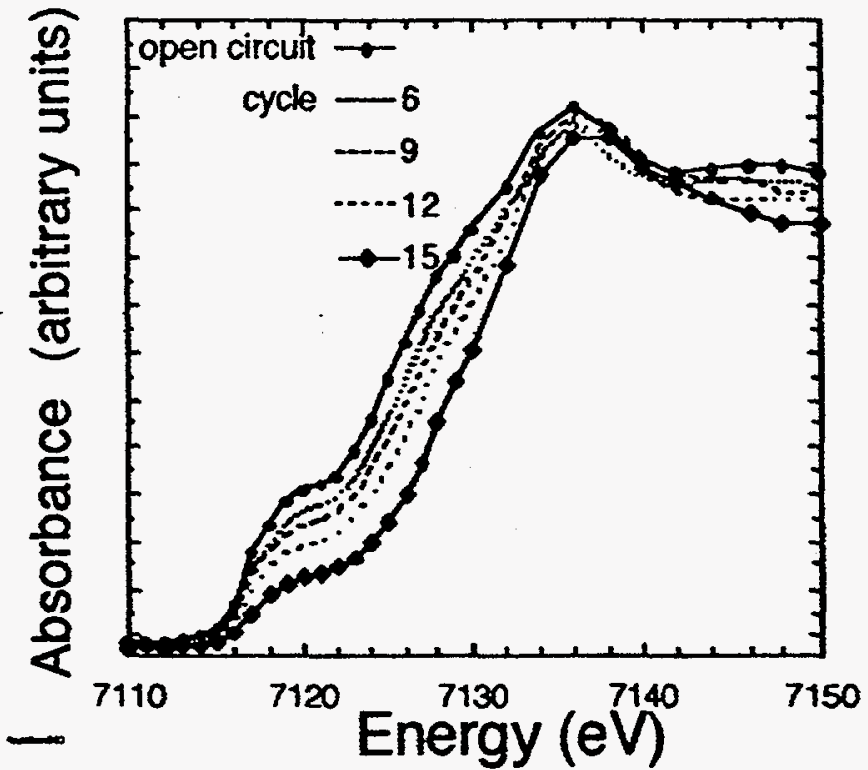

Figure 1. XANES measurements of an Fe film in $0.1 \mathrm{M} \mathrm{NaOH}$ measured at -0.2 $\mathrm{V}$ (mse) during steps between $-1.6 \mathrm{~V}$ amd $-0.2 \mathrm{~V}$ (MSE) .

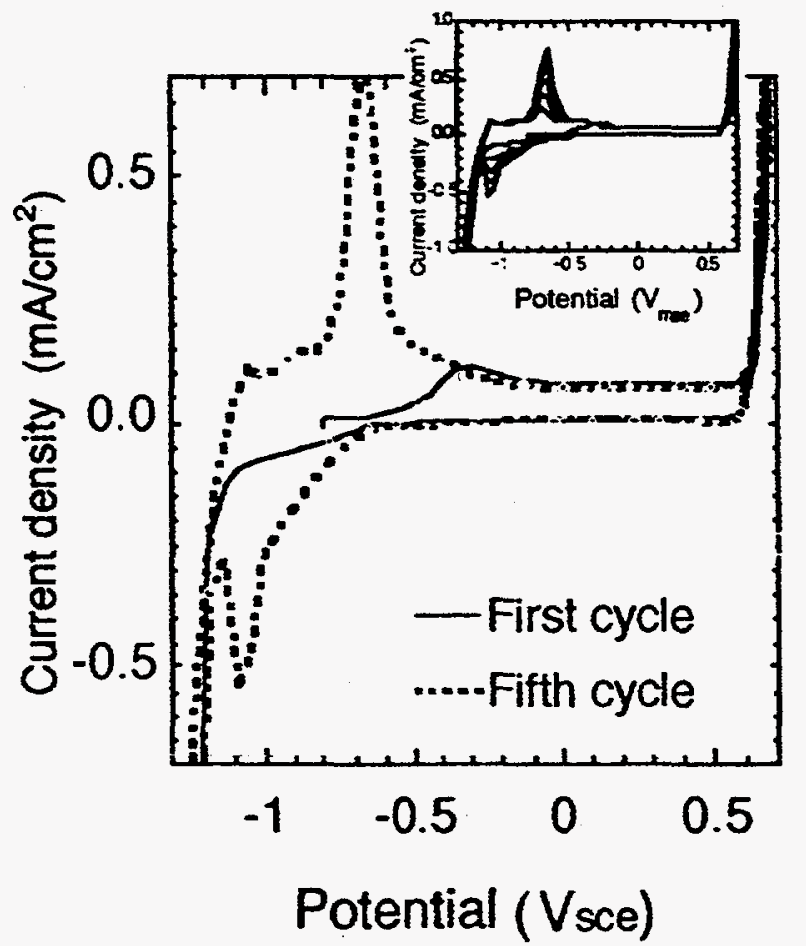

Figure 2. Cyclic voltametry at $10 \mathrm{mV} / \mathrm{s}$ for $\mathrm{Fe}$ in $0.1 \mathrm{M} \mathrm{NaOH}$. The inset shows all 5 cycles 


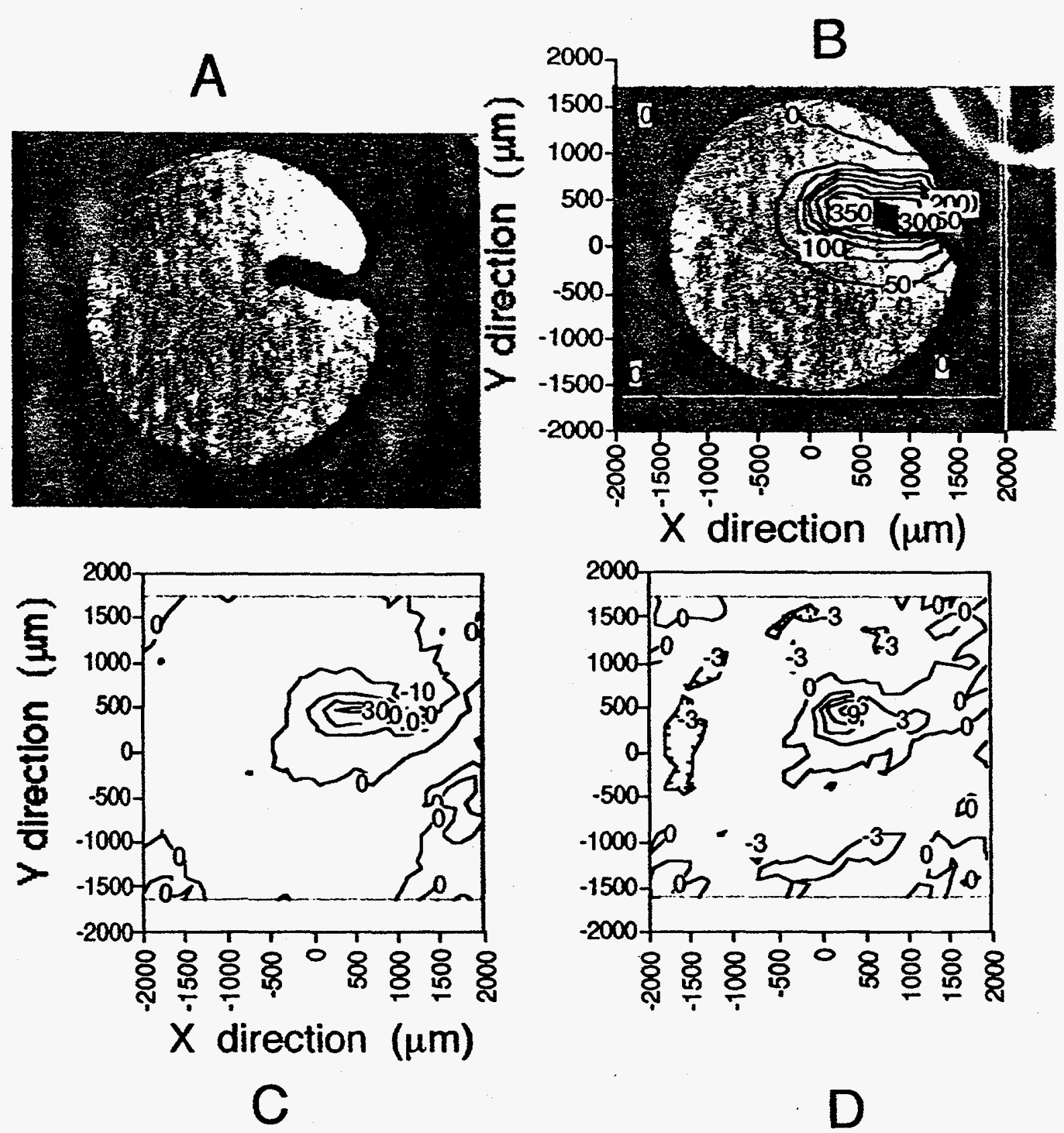

Figure 3. Scanning current density maps and appearance of the Fe surface in $1.0 \mathrm{M} \mathrm{NaCl}$ with $0.1 \mathrm{M} \mathrm{NaOH}$ with and after disconnecting a $\mathrm{Pt}$ wire. A, the appearance of the surface after disconnecting the $\mathrm{Pt}$ wire and $\mathrm{B}$, with superimposed current contours observed while the $\mathrm{Pt}$ was attached. C, and D, are contour maps of the currents half and one hour after detaching he Pt. 


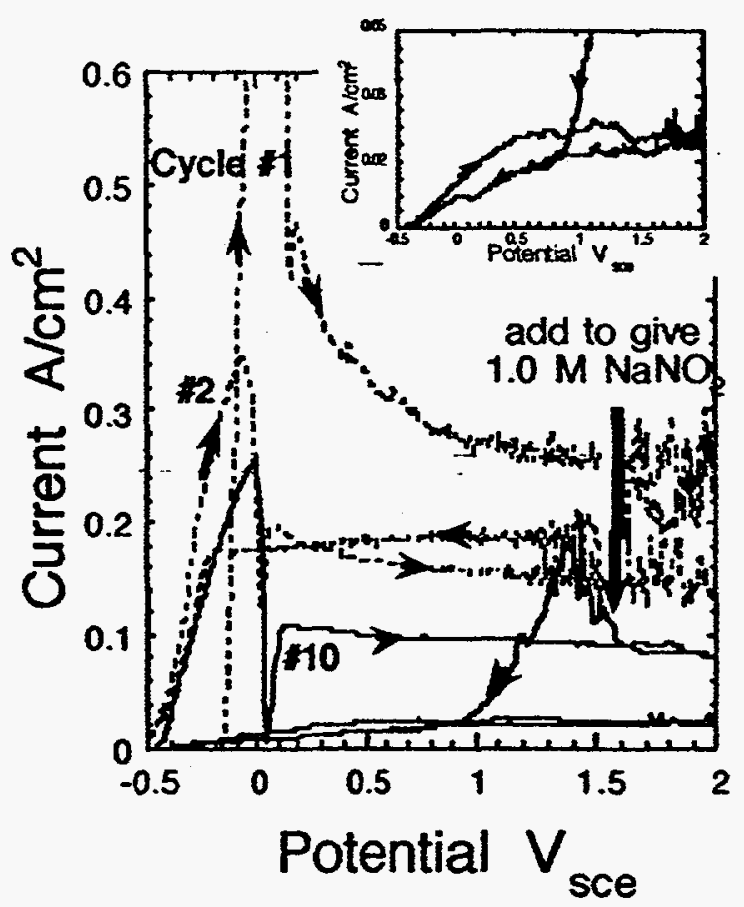

Figure 4. Cyclic voltametry at $5 \mathrm{mV} / \mathrm{s}$ for a wire-type pit electrode in $1.0 \mathrm{M} \mathrm{NaCl}$ with $0.1 \mathrm{M} \mathrm{NaOH}$. On the 10 h cycle $\mathrm{NaNO}_{2}$ was added to give a $1.0 \mathrm{M}$ concentration. The inset shows the behavior of the current after the nitrite was added.

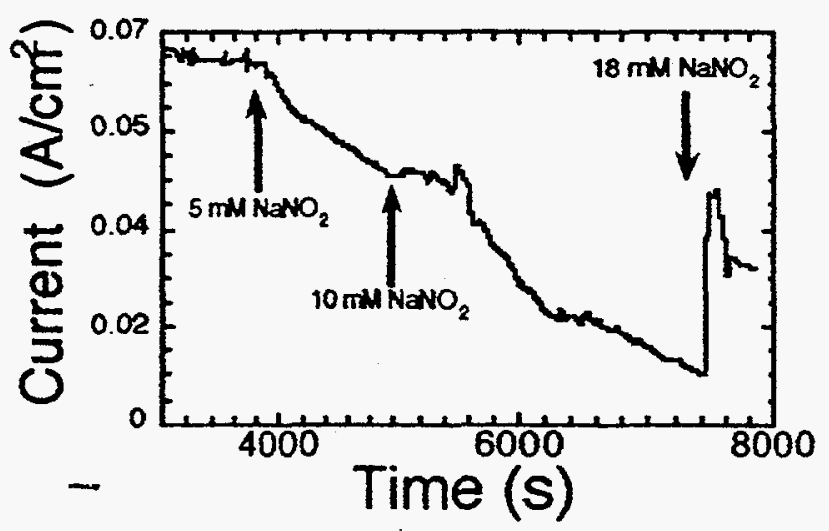

Figure 5. Changes in current for a wire-type pit in $1.0 \mathrm{M} \mathrm{NaCl}$ with $0.1 \mathrm{M} \mathrm{NaOH}$ solution showing decreases on addtion of $\mathrm{NaNO}_{2}$. 